\title{
SPECIFIC VOLUME OF PLASMA AND SERUM PROTEINS IN PREGNANT AND IN PARTURIENT WOMEN AND THEIR NEWBORN CHILDREN AS DERIVED FROM VISCOSITY MEASUREMENTS
}

\author{
BY FRED W. OBERST 1 \\ (From the Department of Obstetrics and Gynecology, State University of Iowa, Iowa City, Iowa)
}

(Received for publication August 14, 1939)

Kunitz (1) reviewed the derivation of a formula developed by Einstein (2) indicating that viscosity is a function of the volume fraction of a dispersed substance, and suggested a modified empirical equation that was found to be more applicable to a large variety of solutions. The complete equation is

$$
\eta=\frac{1+0.5 \varphi}{(1-\varphi)^{4}},
$$

where $\eta$ is the relative viscosity, i.e., the ratio of the absolute viscosity of the suspension to that of the pure solvent. The symbol $\varphi$ stands for the volume fraction occupied by the dispersed substance or solute expressed either in percentage or in cubic centimeters (cc.) per $100 \mathrm{cc}$. of solution. Hence, $\varphi$ divided by the weight of the solute per $100 \mathrm{cc}$. of solution represents the specific volume of the solute. This should be constant for various concentrations of a solute or a suspension unless the solute or suspension is hydrated or solvated to an extent varying with the concentration.

On expansion the equation becomes

$$
\eta=1+4.5 \varphi+12 \varphi^{2}+25 \varphi^{3} \ldots
$$

When $\varphi$ is very small, the equation becomes

$$
\eta=1+4.5 \varphi
$$

and is identical with that derived by Hatschek (3) for the viscosity of suspensions.

Kunitz advanced experimental data to demonstrate that the expanded equation may be applied to practically all solutions or suspensions where the solute or particles are large in comparison with the molecules of the solvent. The values for the specific volumes of various concentrations of sugar and sulphur suspensions, as calculated by this

\footnotetext{
1 Now with the U. S. Public Health Service Hospital, Lexington, Kentucky.
}

equation, are constant and agree with the actual specific volume in the dry state. On the other hand, the values for the specific volumes of solutions of such substances as glycogen, casein, and rubber, as obtained from viscosity measurements, are much higher than those recorded for the dry state, indicating that these substances are intimately associated with a portion of their solvents.

Viscosity measurements and protein determinations have been made on blood plasma and serum to calculate the specific volume of the respective proteins, in terms of the expanded equation.

\section{METHODS AND PROCEDURE}

The viscosities of serum and plasma were determined at $25^{\circ} \pm 0.02^{\circ} \mathrm{C}$. by means of a Poiseuille viscometer as modified by Ostwald, using 2 cc. portions. The relative viscosity $(\eta)$ was obtained by dividing the time $t_{1}$ for serum or plasma by the time $t_{2}$ for isotonic ( 0.9 per cent) sodium chloride. When either the plasma or serum was diluted with a diluting fluid, the corresponding value of $t_{2}$ was used. No correction was made for density of the serum or plasma and the diluting fluid, since this factor would be nearly one, and relatively constant.

The total nitrogen of the serum was determined by the micro-Kjeldahl method (4) and the nonprotein nitrogen by the procedure of Folin and $\mathrm{Wu}$ (5). The protein nitrogen as obtained by subtraction was multiplied by the usual conversion factor, 6.25, to obtain the total protein percentage. Plasma protein was calculated by adding to the serum protein the value for fibrin, as determined by the method of Chandler (6).

To determine $\varphi$ from the expanded equation when $\eta$ is given, one must first plot on graph paper a curve similar to that given by Kunitz (1) on page 717. The values of $\varphi$ for various values of $\eta$ may then be read directly from the curve. 
Preliminary experiments were made to determine the effect of the anticoagulants, potassium oxalate and heparin, on the viscosity of serum and plasma. Approximately 3 to $4 \mathrm{mgm}$. of potassium oxalate or $0.5 \mathrm{mgm}$. of heparin were added to each cc. of whole blood, and half of these amounts to serum.

To determine whether the specific volume of the protein remained constant under different dilutions as low as 0.14 per cent, serum was diluted with distilled water, with isotonic sodium chloride, and with $M / 15$ phosphate buffer, $\mathrm{pH}$ 7.4 .

The plasma and serum of 22 women in late pregnancy were analyzed for viscosity time and for protein concentration. The same analyses were made on the sera of 24 parturient women and of their newborn children (umbilical cord blood).

\section{RESULTS}

The viscosity of both serum and plasma is increased with the amounts of heparin employed but is not changed with potassium oxalate (Table I). Consequently, potassium oxalate was used routinely as the anticoagulant.

TABLE I

The effect of potassium oxalate and heparin on the viscosity time of serum and plasma *

\begin{tabular}{c|c|c|c|c|c}
\hline \hline & \multicolumn{3}{|c|}{ Serum } & \multicolumn{2}{c}{ Plasma } \\
\cline { 2 - 6 } Number & $\begin{array}{c}\text { Without } \\
\text { K oxalate }\end{array}$ & $\begin{array}{c}\text { With } \\
\text { K oxalate }\end{array}$ & $\begin{array}{c}\text { With } \\
\text { heparin }\end{array}$ & $\begin{array}{c}\text { With } \\
\text { heparin }\end{array}$ & $\begin{array}{c}\text { With } \\
\text { K oxalate }\end{array}$ \\
\hline & seconds & seconds & seconds & seconds & seconds \\
1 & 115.5 & 115.0 & & 131.5 & 121.5 \\
2 & 116.5 & 116.7 & & 130.3 & 119.7 \\
3 & 121.0 & 120.5 & & 137.1 & 129.8 \\
4 & 113.4 & 113.2 & 115.8 & 128.7 & 121.5 \\
5 & 115.4 & 116.0 & 120.0 & 134.8 & 125.2 \\
\hline
\end{tabular}

* Viscosity of serum and plasma are expressed in seconds as compared with $\mathbf{7 1 . 2}$ seconds for water at a temperature of $25.0^{\circ} \mathrm{C} . \pm 0.02^{\circ} \mathrm{C}$.

The results of diluting serum with distilled water, with isotonic chloride, and with $M / 15$ phosphate buffer, $\mathrm{pH} 7.4$, to give various protein concentrations are given respectively in Tables II-A, II-B, and II-C. The volume fraction of the protein in each experiment is decreased by the dilution, but its specific volume remains constant.

The protein content and relative viscosity of serum and plasma, together with the volume fraction and the specific volume of their respective proteins in late pregnancy, are presented in Table III. In each case the specific volume of the serum protein is slightly less than that of the plasma protein, the average values being 1.62 and 1.74 . The relative viscosity of serum is lower than that of plasma, but the decrease is disproportionate to the decreased serum protein, thus accounting for the lower specific volume of the serum protein.

The data on the serum from parturient women and their newborn children (cord blood), as given in Table IV, indicate that all of the constituents determined are definitely lower in cord blood serum than in maternal blood serum. The decreased relative viscosity of cord blood serum is not proportional to the decreased protein content;

TABLE II-A

The effect on the specific volume of the protein as determined by viscosity measurements of diluting serum with distilled water

\begin{tabular}{c|c|c|c|c}
\hline \hline $\begin{array}{c}\text { Protein } \\
C\end{array}$ & $\begin{array}{c}\text { Time } \\
t_{1}\end{array}$ & $\begin{array}{c}\text { Relative } \\
\text { viscosity } \\
\eta\end{array}$ & $\begin{array}{c}\text { Volume } \\
\text { fraction of } \\
\text { the protein } \\
\varphi\end{array}$ & $\begin{array}{c}\text { Specific } \\
\text { volume of } \\
\text { the protein } \\
\varphi\end{array}$ \\
\hline $\begin{array}{c}\text { grams per } \\
100 \text { cc. }\end{array}$ & seconds & & per cent & \\
7.20 & 116.4 & 1.634 & 10.50 & 1.46 \\
6.72 & 113.3 & 1.590 & 9.93 & 1.48 \\
5.76 & 105.8 & 1.486 & 8.50 & 1.48 \\
4.80 & 98.9 & 1.389 & 7.10 & 1.48 \\
3.36 & 89.3 & 1.254 & 5.00 & 1.49 \\
2.88 & 86.6 & 1.216 & 4.30 & 1.49 \\
2.40 & 85.0 & 1.194 & 3.90 & 1.62 \\
1.68 & 80.3 & 1.128 & 2.70 & 1.61 \\
0.72 & 75.4 & 1.058 & 1.30 & 1.81 \\
0.00 & $71.2 *$ & 1.000 & & \\
\hline
\end{tabular}

* This is the value for $t_{2}$.

TABLE II-B

The effect on the specific volume of the protein as determined by viscosity measurements of diluting serum with isotonic sodium chloride (0.90 per cent)

\begin{tabular}{c|c|c|c|c}
\hline \hline $\begin{array}{c}\text { Protein } \\
C\end{array}$ & $\begin{array}{c}\text { Time } \\
t_{1}\end{array}$ & $\begin{array}{c}\text { Relative } \\
\text { viscosity } \\
\eta\end{array}$ & $\begin{array}{c}\text { Volume } \\
\text { fraction of } \\
\text { the protein } \\
\varphi\end{array}$ & $\begin{array}{c}\text { Specific } \\
\text { volume of } \\
\text { the protein } \\
\varphi\end{array}$ \\
\hline $\begin{array}{c}\text { grams per } \\
100 \text { cc. }\end{array}$ & seconds & & per cent & \\
8.20 & 136.5 & 1.885 & 13.47 & 1.64 \\
7.18 & 122.9 & 1.698 & 11.27 & 1.57 \\
6.15 & 112.7 & 1.557 & 9.50 & 1.54 \\
4.10 & 95.4 & 1.318 & 6.00 & 1.46 \\
2.05 & 82.6 & 1.141 & 2.92 & 1.42 \\
1.03 & 77.4 & 1.069 & 1.50 & 1.46 \\
0.16 & 73.1 & 1.010 & 0.20 & 1.25 \\
0.00 & $72.4 *$ & 1.000 & & \\
\hline
\end{tabular}

* This is the value for $t_{2}$. 
TABLE II-C

The effect on the specific volume of the protein as determined by viscosity measurements of diluting serum with phosphate buffer, pH. 7.4

\begin{tabular}{c|c|c|c|c}
\hline \hline $\begin{array}{c}\text { Protein } \\
C\end{array}$ & $\begin{array}{c}\text { Time } \\
t_{1}\end{array}$ & $\begin{array}{c}\text { Relative } \\
\text { viscosity } \\
\eta\end{array}$ & $\begin{array}{c}\text { Volume } \\
\text { fraction of } \\
\text { the protein } \\
\varphi\end{array}$ & $\begin{array}{c}\text { Specific } \\
\text { volume of } \\
\text { the protein } \\
\varphi\end{array}$ \\
\hline $\begin{array}{c}\text { grams per } \\
100 \text { cc. }\end{array}$ & seconds & & per cent & \\
7.15 & 118.3 & 1.594 & 9.98 & 1.40 \\
6.44 & 112.0 & 1.509 & 8.88 & 1.38 \\
5.72 & 106.7 & 1.438 & 7.80 & 1.36 \\
4.76 & 99.9 & 1.346 & 6.48 & 1.36 \\
3.58 & 89.6 & 1.208 & 4.11 & 1.15 \\
2.38 & 85.5 & 1.152 & 3.13 & 1.32 \\
1.43 & 80.5 & 1.085 & 1.85 & 1.29 \\
0.57 & 76.9 & 1.036 & 0.81 & 1.42 \\
0.14 & 74.6 & 1.005 & 0.10 & 0.71 \\
0.00 & $74.2 *$ & 1.000 & & \\
\hline
\end{tabular}

* This is the value for $t_{2}$.

TABLE III

Specific volumes of serum and plasma proteins in late pregnancy as derived from viscosity measurements

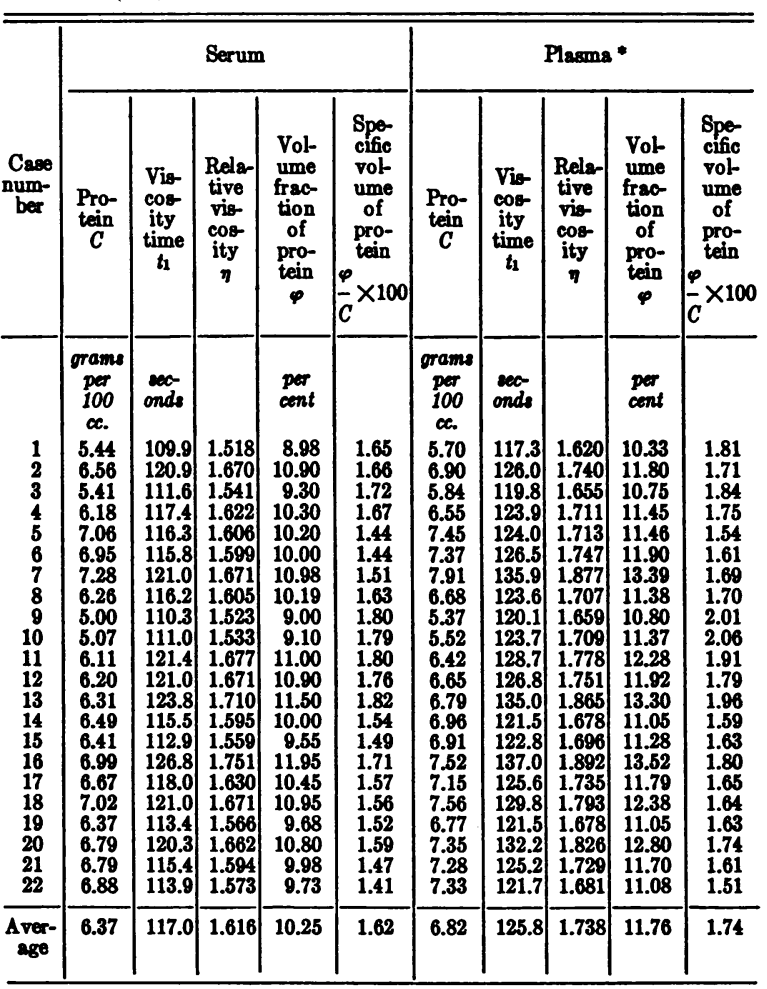

* Potassium oxalate was used as the anticoagulant. Fibrin was determined directly and the value added to serum protein to obtain the total plasma protein values.
TABLE IV

Specific volumes of serum proteins in parturient women and their newborn children as derived from viscosity measurements

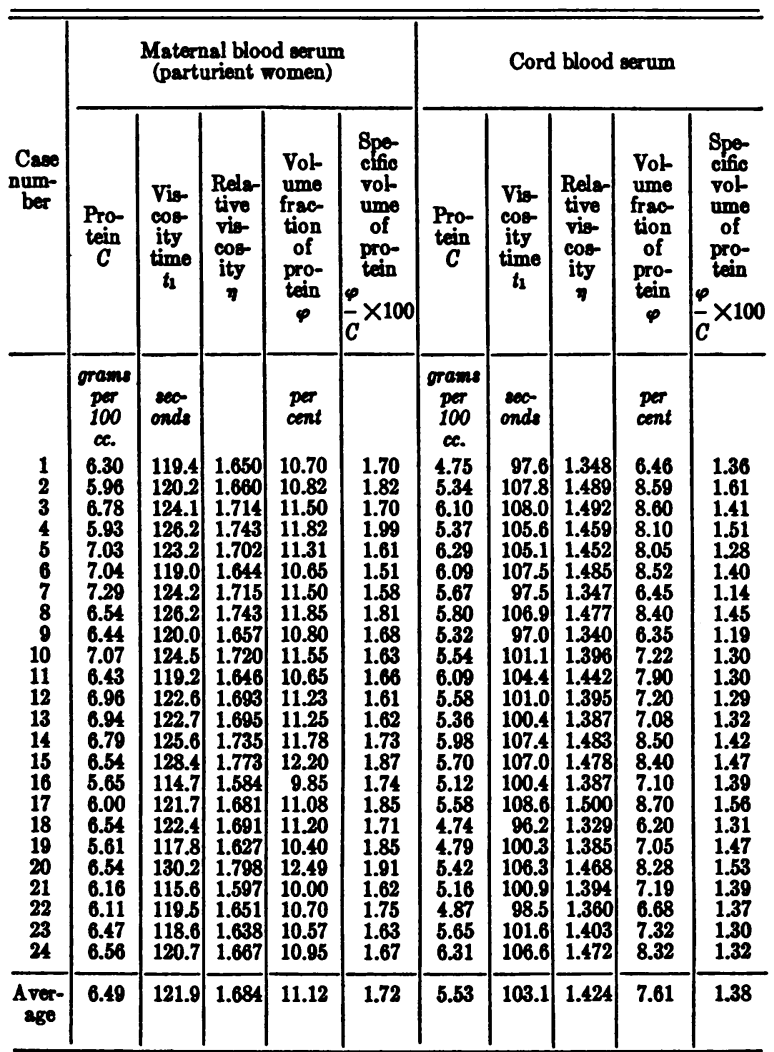

hence, if all other factors are equal, the specific volume of cord serum protein is lower than maternal serum protein.

\section{DISCUSSION}

No satisfactory reason can be given why the specific volumes of plasma and serum proteins differ in the same blood, and in the sera of parturient women and their newborn children. However, a number of interesting possibilities may be offered. Since plasma and serum proteins differ only by their fibrinogen content, it is quite probable that the general shape or configuration of the serum protein molecule has been changed due to the separation of fibrinogen. The distribution of the electric charges on these may also be altered. These factors must play a definite part in viscosity measurements which in turn might lead one to false conclusions regarding specific volume of plasma and serum proteins in solution. 
Fibrinogen, having a higher molecular weight than serum albumin or globulin, leads one to suspect it as being the main factor responsible for the increase in viscosity of plasma over serum. The concentration of other constituents, such as lipids and electrolytes, is presumably the same in the serum as in the plasma. The higher proportion of globulin in maternal blood (7), as compared with cord blood, probably explains the increase in the viscosity of the maternal serum containing a given weight of total protein, and hence, a higher specific volume. It has been shown by Nugent and Towle (8) that as the albumin-globulin ratio for a given concentration of protein solution increases, the relative viscosity is decreased, an observation which is in agreement with the present study.

If it is assumed that blood proteins are hydrated colloids, the data obtained by application of the empirical equation would indicate that the plasma proteins might be more hydrated than the serum proteins, and that the serum proteins in parturient women might be more hydrated than those of their newborn children. It has been reported by du Nouy (9) that the specific volume of rabbit serum protein in solution is 1.645 and in the dry state is 0.785 .

Not all investigators agree as to the state of the water in blood plasma. Sunderman (10) concluded from freezing point experiments that, within 2 per cent, the limit of error of his measurements, the content of free water of serum is equal to the content of total water. From viscosity measurements and data on the protein concentration of blood serum, Fishberg (11) concluded that the actual volume of a protein in solution at any dilution is proportional to the dilution and that it is unnecessary to assume any hydration of the protein molecules. He further indicated that variations in urea and cholesterol concentrations have a profound influence upon the viscosity of blood serum.

In hydremia in children Jochims (12) found a parallel fall in plasma viscosity and protein. The specific viscosity remained constant, indicating that the excess water of the plasma in no way disturbed the collodial nature of the proteins. He also stated (13) that the viscosity of the blood plasma in 21 normal children was not related directly to the protein concentration as demanded by Einstein's formula.

\section{SUM MARY}

1. Potassium oxalate does not change the viscosity time of serum or plasma, but heparin produces an increase.

2. Dilution of serum with distilled water, isotonic saline, or with $M / 15$ phosphate buffer solution to a protein concentration as low as 1 per cent does not alter the specific volume of the protein.

3. The specific volume of plasma protein is slightly higher than that of serum protein from the same blood sample.

4. The specific volume of serum protein is higher in parturient women than in their newborn children (cord blood).

5. Factors involved in the variation of the specific volume of proteins are discussed.

\section{BIBLIOGRAPHY}

1. Kunitz, M., Empirical formula for relation between viscosity of solution and volume of solute. J. General Physiol., 1926, 9, 715.

2. Einstein, A., Quoted by Kunitz (1). Ann. Physik., 1906, 19, 289; 1911, 34, 591.

3. Hatschek, E., Die Viscosität der Dispersoide. Quoted by Kunitz (1). Ztschr. f. Chem. u. Indust. d. Kolloide, 1910, 7, 301.

4. Hawk, P. B., and Bergeim, O., Practical Physiological Chemistry, P. Blakiston's Son and Co., Philadelphia, 1931, 10th ed., p. 449.

5. Folin, O., and Wu, H., A system of blood analysis. J. Biol. Chem., 1919, 38, 81.

6. Chandler, J., Determination of fibrin in blood plasma. J. Lab. and Clin. Med., 1927, 12, 1092.

7. Achard, C., Bariety, M., and Codounis, A., L'équilibre protéique du sérum comparé dans le sang de mère et le sang du cordon ombilical. Compt. rend. Soc. de biol., 1929, 102, 984.

8. Nugent, R. L., and Towle, L. W., Albumin-globulin ratios in synthetic solutions from specific gravity and relative viscosity measurements. Proc. Soc. Exp. Biol. and Med., 1935, 33, 374.

9. du Nouy, P. L., Viscosity of blood serum as function of temperature. J. General Physiol., 1929, 12, 363.

10. Sunderman, F. W., State of water in blood serum. Am. J. M. Sc., 1931, 181, 154.

11. Fishberg, E. H., Significance of changes of viscosity in pathological sera. J. Biol. Chem., 1929-30, 85, 465.

12. Jochims, J., Sur Frage der Wasserbindungsverhältnisse des Kindlichen Blutplasmas. Klin. Wchnschr., 1930, 9, 2115.

13. Jochims, J., Viscosimetrische untersuchungen über die Wasserbindung der Plasmakolloide; die Wasserbindung der Eiweisskörper im normalen Blutplasmas. Arch. f. a. ges. Physiol., 1932, 230, 255. 